\title{
TERMINATION OF PREGNANCY BY HYPOPHYSECTOMY IN THE PIG
}

\author{
R. R. KRAELING AND B. J. DAVIS \\ U.S. Department of Agriculture, Agricultural Research Service, \\ Animal Physiology and Genetics Institute, Beltsville, Maryland 20705, U.S.A.
}

(Received 27th Fuly 1973)

\begin{abstract}
Summary. Pregnant crossbred gilts were hypophysectomized or subjected to sham hypophysectomy at 70,80 or 90 days of gestation. Eleven of twelve gilts subjected to the sham operation maintained pregnancy to term and farrowed live pigs. One gilt subjected to the sham operation at 80 days aborted approximately $48 \mathrm{hr}$ after surgery. All hypophysectomized gilts aborted approximately $60 \mathrm{hr}$ after surgery. These data indicate that the placenta of the pig failed to secrete progestagens or a luteotrophic substance which would maintain pregnancy and that the pig requires the presence of the pituitary through to at least Day 90 of gestation for the maintenance of pregnancy.
\end{abstract}

The effect of hypophysectomy on pregnancy in various mammalian species has been extensively reviewed by Zarrow (1961), Deanesly (1966) and van Tienhoven (1968). Hypophysectomy at any time during gestation interrupted pregnancy in the rabbit and ferret and, when performed in early gestation, generally interrupted pregnancy in other species. In late gestation, hypophysectomy failed to terminate pregnancy in rats, mice, guinea-pigs, sheep, monkeys and women. The subsequent maintenance of pregnancy in the sheep, guinea-pig, monkey and woman was probably due primarily to progestagen secretion by the placenta whereas, in the rat and mouse, it was probably due to a luteotrophin secreted by the placenta. Luteal maintenance after hypophysectomy of the hysterectomized guinea-pig indicates that the CL in this species may have an inherent life-span independent of pituitary support (Rowlands, 1962; Heap, Perry \& Rowlands, 1967). It has also been well documented that the placenta of the woman and monkey and the endometrium of the mare secrete gonadotrophins during pregnancy.

In the pig, hypophysectomy between Days 4 and 70 of gestation has resulted in termination of pregnancy (du Mesnil du Buisson, Léglise, Anderson \& Rombauts, 1964; du Mesnil du Buisson \& Denamur, 1969). Du Mesnil du Buisson \& Denamur (1969) observed that sows in which the hypophysial stalk was transected on Day 50 aborted within 6 days; those in which the stalk was transected on Day 70 or 90 , however, maintained gestation until slaughter 20 days later. The purpose of our study was to determine the effect of hypophysectomy on the maintenance of pregnancy in the pig at 70,80 and 90 days of gestation. 
Twenty-four pregnant crossbred Duroc and Yorkshire gilts were randomly assigned to a $2 \times 3$ factorial arrangement of treatments with four gilts per treatment. Treatment variables were hypophysectomy or sham hypophysectomy on Days 70, 80 or 90 of gestation. The hypophysectomy and sham hypophysectomy operations were performed according to the technique described by du Mesnil du Buisson, Léglise \& Chodkiewicz (1964) as modified by Kraeling (1973). The sham hypophysectomy procedures included removal of a section of the frontal-parietal bone, reflection of the dura mater from the left cerebral hemisphere and elevation of the left cerebral hemisphere for $10 \mathrm{~min}$ : the approximate time of elevation during hypophysectomy. All gilts ate and drank unassisted, walked steadily and maintained normal heart rate and body temperature by 6 to $10 \mathrm{hr}$ after surgery.

Eleven of the twelve gilts subjected to sham operation maintained gestation to term and farrowed live pigs that appeared normal. One gilt subjected to sham operation at 80 days aborted approximately $48 \mathrm{hr}$ after surgery which may have resulted from difficulty in oxygenating this particular gilt during surgery.

All hypophysectomized gilts aborted within approximately $60 \mathrm{hr}$ of surgery. Precise timing of abortion was difficult because many gilts aborted during the night. Two gilts hypophysectomized on Day 70, three on Day 80 and all four gilts hypophysectomized on Day 90 of gestation died during abortion. Because these gilts were in excellent condition after surgery and fluids and membranes began passing from the vagina before death in most gilts, we assume these gilts died due to stress of abortion. Autopsies were performed on those gilts which died during abortion. Those which survived abortion were killed several days later. Fetuses were dead, but appeared normal without discoloration of the skin or other evidence that fetal death preceded abortion. The CL of the hypophysectomized gilts at the time of abortion were pale, and histological examination of the luteal tissue revealed pycnotic cells indicative of luteal regression.

Du Mesnil du Buisson \& Léglise (1963) have demonstrated that CL formation after ovulation and CL development and function occurred after hypophysectomy on the day of oestrus or on Day 2, 5, 6, 8 or 10 after oestrus. Although these CL were small when examined between Days 2 and 14 after oestrus, they contained concentrations of progesterone similar to those of intact pigs during the same period of the luteal phase of the oestrous cycle. Work by du Mesnil du Buisson \& Léglise (1963), Anderson, Leglise, du Mesnil du Buisson \& Rombauts (1965), Anderson, Dyck, Mori, Henricks \& Melampy (1967) and du Mesnil du Buisson \& Denamur (1969) has demonstrated that the pig CL requires hypophysial luteotrophic support for maintenance beyond the luteal phase of the oestrous cycle.

The results of this study, in combination with those of du Mesnil du Buisson, Léglise, Anderson \& Rombauts (1964) and du Mesnil du Buisson \& Denamur (1969), indicate that the CL of pregnancy in the pig requires continuous pituitary luteotrophic support. Du Mesnil du Buisson \& Denamur (1969) have reported that pregnancy was maintained in six hypophysectomized sows through 10 days of exogenous progesterone treatment while the CL had regressed during this 10-day period; which indicates that maternal ACTH, TSH and 
GH are not necessary for fetal survival. In this study, abortion was probably caused by CL regression due to the absence of a luteotrophic substance rather than fetal death due to the absence of other maternal pituitary hormones such as ACTH, TSH or growth hormone. These results provided no evidence that the pig placenta secretes sufficient quantities of progestagens to maintain pregnancy, as in the sheep, guinea-pig, monkey and woman, or that the placenta secretes luteotrophic substance, as in the rat and mouse. Like the ferret and rabbit, the pig probably requires the presence of the pituitary throughout gestation for the maintenance of pregnancy.

The authors thank Miss Shirley Harris, Mr Kenneth Bender and Mr Lawrence Meeks for their valuable assistance.

\section{REFERENGES}

Anderson, L. L., Dyck, G. W., Mori, H., Henricks, D. M. \& Melampy, R. M. (1967) Ovarian function in pigs following hypophysial stalk transection or hypophysectomy. Am. F. Physiol. 212, 1188.

Anderson, L. L., Léglise, P. G., du Mesnil du Buisson, F. \& Rombauts, P. (1965) Interaction des hormones gonadotropes et de l'utérus dans le maintien du tissue lutéal ovarien chez la truie. C. r. hebd. Séanc. Acad. Sci., Paris, 261, 3675.

Deanesty, R. (1966) The endocrinology of pregnancy and foetal life. In: Marshall's Physiology of Reproduction, Vol. III, pp. 891. Ed. A. S. Parkes. Longmans Green, London.

du Mesnir du Buisson, F. \& Denamur, R. (1969) Mécanismes du contrôle de la fonction lutéale chez la truie, la brébis et la vache. 3rd Int. Congr. Endocr, Mexico, Excerpta med. Int. Congr. Ser. 184, 927.

du Mesnil du Bursson, F. \& LÉglise, P. C. (1963) Effet de l'hypophysectomie sur les corps jaunes de la truie. Résultats préliminaires. C. r. hebd. Séanc. Acad. Sci., Paris, 257, 261.

du Mesnil du Buisson, F., LÉglise, P. G., Anderson, L. L. \& Rombauts, P. (1964) Maintien des corps jaunes et de la géstation de la truie au course de la phase préimplantatoire après hypophysectomie. Int. Congr. Anim. Reprod. Artif. Insem., Trento, 3, 571.

du Mesnil du Bursson,F., LÉglise, P. C. \& Ghodkiewicz, J. P. (1964). Technique de l'hypophysectomie par voie transfrontale sus-orbitaire chez le porc. Annls Biol. anim. Biochim. Biophys. 4, 229.

Heap, R. B., Perry, J. S. \& Rowlands, I. W. (1967) Corpus luteum function in the guinea-pig; arterial and luteal progesterone levels, and the effects of hysterectomy and hypophysectomy. F. Reprod. Fert. 13, 537 .

Kraeling, R. R. (1973) A modified supraorbital approach to hypophysectomy in the pig. Am. F. vet. Res. 34, 283.

RowLAnds, I. W. (1962) The effect of oestrogens, prolactin and hypophysectomy on the corpora lutea and vagina of hysterectomized guinea-pigs. F. Endocr. 24, 105.

van Tienhoven, A. (1968) Reproductive physiology of vertebrates. Saunders, Philadelphia.

Zarrow, M. X. (1961) Gestation. In: Sex and Internal Secretions, Vol. II, p. 958. Ed. W. G. Young. Williams \& Wilkins, Baltimore. 